\title{
Taking Money from Strangers: Traders' Responses to Banknotes and the Risks of Forgery in Late Georgian
}

\section{London}

\section{Hannab Barker $\odot$ and Sarab Green}

\begin{abstract}
Selling to strangers was a significant occupational hazard for retailers in late Georgian Britain, one that was hard to avoid. The dangers were especially great in larger towns and cities, where shopkeepers were dependent on a steady stream of passing trade composed of a large number of customers that they did not know. Though traders risked financial loss and even possible prosecution by accepting counterfeit banknotes, refusal to accept them meant losing vital custom. In areas of growing urban populations, tradesmen and women thus faced an increasingly tricky dilemma in their day-to-day business as they dealt with more strangers whose trustworthiness and personal credit were extremely hard to gauge, at a time when banknote forgery was on the rise. The decisions that retailers made about both banknotes and the individuals who presented them for payment illustrate some of the ways that town dwellers sought to navigate the rising anonymity of urban society in the late eighteenth and early nineteenth centuries. This article suggests that traders relied on a series of techniques that in previous experience usually worked: examining banknotes and those strangers who presented them with care, relying on the expertise of neighbors and members of their household, and dealing by preference with individuals who appeared to be linked to their local community. These behaviors demonstrate that "modernity" might have affected the lives and outlooks of ordinary Londoners in unexpected and contradictory ways, some strongly linked to older forms of society.
\end{abstract}

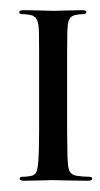

n November 1817, the Times reported a case brought before the Queen Square magistrates court in Westminster concerning banknote forgery. In custody was "a respectable looking man" named Stephen Clifton, who had been arrested for allegedly passing a counterfeit Bank of England note. William King, a grocer and tea dealer who traded on Bury Street in Chelsea, reported that on the previous Monday night, Clifton came to his shop alone and asked for a

Hannah Barker is professor of British history at the University of Manchester. Sarah Green was a $\mathrm{PhD}$ student in history at the University of Manchester, and her archival research forms the basis for this article, which is dedicated to her memory. Helen Metcalfe also made a vital contribution trawling through Old Bailey Online records, while Tom Scriven located documents at the National Archives. The authors are grateful to Sasha Handley, Craig Muldrew, Jon Stobart, and Alexia Yates for their incisive comments on earlier drafts, to the anonymous reviewers for this journal who offered very helpful critiques and suggestions, and to the participants of the Eighteenth-Century Worlds Seminar, University of Liverpool and the Long Eighteenth Century Seminar, University of Oxford, for their stimulating thoughts and questions. Please direct any correspondence to hannah.barker@manchester.ac.uk. 
quarter pound of tea, which King duly weighed and wrapped in paper before accepting a $£ 1$ note in payment. According to King, he then "went immediately into his parlour, which adjoins the shop" with the note in his hand, where his wife, "who had heard what passed. . . reproached him for giving change for a note to an entire stranger." King claimed to have answered that "it appeared to be a good one, for it had the water-mark."

The sound of a whistle outside, however, made him head into the street. According to King, "he had not gone far before he heard another whistle not far from him, and walking in the direction from which the sound came, he saw the prisoner, by the light of a window, cross the street and go up to two men on the other side." One of these men was said to have come out of the neighboring shop of the greengrocer, Mr. Shaw. King claimed that he passed the men "as near as he could" and heard one of them say, "Well, we have done them cleverly." At that point, King described himself as "pretty well convinced how the matter was." Quickly checking with Mr. Shaw's shopman, and hearing that he, too, had just exchanged a quarter pound of tea for a pound note, King was said to have told him, "It is a forged one you may rely on it." King and Skinner pursued all three men, holding Clifton until a constable arrived, while the other two escaped. ${ }^{1}$

Though Stephen Clifton was sentenced to fourteen years' transportation for his crime, ${ }^{2}$ he and his accomplices were not the only ones who took risks during this episode. Selling to strangers was a significant occupational hazard for retailers in late Georgian Britain, but one that was hard to avoid. Nowhere were the dangers greater than in larger towns and cities, where shopkeepers depended on a steady stream of passing trade, including significant numbers of customers that they did not know. ${ }^{3}$ The obvious risks of offering credit to unfamiliar buyers could be avoided-at least in theory-by restricting them to "ready money" purchases, but the widespread problem of forgery meant that the coins and banknotes exchanged for goods and services could themselves be unreliable. This was especially true when new lower-denomination notes were issued between 1797 and 1821, an innovation that was accompanied by an upsurge in counterfeiting and in the crime of "uttering"- presenting a note for payment that the individual knows to be counterfeit, with the intent to defraud. ${ }^{4}$ If a tradesperson took a forged note from a stranger, there was limited chance of seeking recompense. Traders thus risked financial loss by accepting a counterfeit, but even more dangerous was the possibility that if they passed it on, they might be accused of uttering themselves. However, a refusal to accept banknotes (and other forms of legal tender such as coins and bills of exchange,

\footnotetext{
${ }^{1}$ Times, 6 November 1817. All references to the Times are to the London newspaper.

${ }^{2}$ Trial of Stephen Clifton, 5 December 1817, t18171203-34, Old Bailey Proceedings Online, https:// www.oldbaileyonline.org/browse.jsp?div $=\mathrm{t} 18171203-34$. (Citations to this database are hereafter abbreviated $\mathrm{OBP})$.

${ }^{3}$ James G. Carrier, Gifts and Commodities: Exchange and Western Capitalism since 1700 (London, 1995), 74-83; Peter Burke, "Imagining Identity in the Early Modern City" in Imagining the City, vol. 1, The Art of Urban Living, ed. Christine Emden, Catherine Keen, and David Midgley (Oxford, 2006), 23-38; James Vernon, Distant Strangers: How Britain Became Modern (Berkeley, 2014).

${ }^{4}$ Randall McGowen, "The Bank of England and the Policing of Forgery, 1797-1821," Past and Present, no. 186 (2005): $81-116$, at 85-89.
} 
which were also prone to forgery) meant losing vital custom. ${ }^{5}$ Tradesmen and women in growing urban populations across Britain thus faced an increasingly tricky dilemma as in their day-to-day business they dealt with rising numbers of strangers whose trustworthiness and personal credit were extremely hard to gauge while at the same time banknote forgery was on the increase. The decisions that retailers made about both banknotes and those who presented them for payment in this context illustrate some of the ways that town dwellers sought to navigate the rising anonymity of urban society in the late eighteenth and early nineteenth centuries.

Craig Muldrew and others have suggested that trust or credit was a crucial factor in many of the economic transactions and credit networks of early modern England, and specifically among smaller communities in which one's personal or household credit and reputation rested on the direct cooperation of neighbors or known associates as part of a dense network of cooperation and obligation. ${ }^{6}$ This understanding of the role of trust draws on the work of sociologists investigating its functional properties. These scholars commonly argue that the transition from premodern to modern societies - in part defined by the growth of towns and cities-brings about changes in the way trust operates, which alters the nature of social and economic relations. In particular, they identify a shift from particularistic or "thick" forms of trust embedded in highly personal relations such as networks of family, friends, and neighbors, to more "social," "generalized," or "thin" forms of trust that involve a greater number of ties and less dense relations and eventually become centered on institutions and abstract capacities thought to reside within them. ${ }^{7}$ The move from premodern forms of society, where trust was based largely on interpersonal relations in smaller communities, to modern urban societies functioning according to new forms of social trust must be assumed to be both slow and uneven. The development of modern societies in which complex and stable

5 Julian Hoppit, "The Use and Abuse of Credit in Eighteenth-Century England," in Business Life and Public Policy, ed. Neil McKendrick and R. B. Outhwaite (Cambridge, 2002), 64-78, at 70-71; John Styles, "Our Traitorous Money Makers': The Yorkshire Coiners and the Law, 1760-83," in An Ungovernable People: The English and Their Law in the Seventeenth and Eighteenth Centuries, ed. John Brewer and John Styles (London, 1980), 172-249. On the insecurity of lower middling finances and the potential for disaster, see Tawny Paul, The Poverty of Disaster: Debt and Insecurity in Eighteenth-Century Britain (Cambridge, 2019), 67-94.

${ }^{6}$ Craig Muldrew, The Economy of Obligation: The Culture of Credit and Social Relations in Early Modern England (Basingstoke, 1998), 123-47; Shani D'Cruze, “The Middling Sort in Eighteenth-Century Colchester: Independence, Social Relations and the Community Broker," in The Middling Sort of People: Culture, Society and Politics in England, 1550-1800, ed. Jonathan Barry and Christopher Brooks (Basingstoke, 1994), 181-207; Steven Shapin, A Social History of Truth: Civility and Science in Seventeenth-Century England (Chicago, 1994); Robin Pearson and David Richardson, "Business Networking in the Industrial Revolution," Economic History Review 54, no. 4 (2001), 657-79, at 672-75; Sheryllynne Haggerty, "Merely for Money"? Business Culture in the British Atlantic, 1750-1815 (Liverpool, 2012), 67-84, 97130; K. Tawny Paul, "Credit, Reputation, and Masculinity in British Urban Commerce: Edinburgh, c. 1710-70,” Economic History Review 66, no. 1 (2013): 226-48; Paul, Poverty of Disaster.

7 Robert D. Putnam, Bowling Alone: The Collapse and Renewal of American Community (New York, 2000), 136-38; see also Niklas Luhmann, Trust and Power (Chichester, 1979); Diego Gambetta, "Can We Trust Trust?," in Trust: Making and Breaking Co-operative Relations, ed. Diego Gambetta (Oxford, 1988), 213-37; Anthony Giddens, The Consequences of Modernity (Stanford, 1990); Ulrich Beck, Risk Society: Towards a New Modernity (London, 1992); Eric M. Uslaner, The Moral Foundations of Trust (Cambridge, 2002), 94-107. 
social, political, and economic organizations such as companies, banks, monetary systems, and bureaucratic organizations are broadly trusted, in part by virtue of their possession of expert systems of knowledge, ${ }^{8}$ cannot appear overnight. At the same time, a paucity of efficient regulatory control means that the confidence that individuals might have in systems and bodies to police transgressions of trust and uphold standards can be wholly or partly absent. During such a period of transformation, as society becomes more heterogeneous and anonymous, interpersonal trust can be increasingly difficult to generate, since trusting in those about whom one knows little is inherently risky. 9

Such developments might be particularly problematic for those involved in commerce, since low levels of social trust are seen as an obstacle to economic activity. ${ }^{10}$ Yet as the economy grew and commercial transactions proliferated during the eighteenth and nineteenth centuries, rising anonymity did not seem to act as a major brake on retailing. ${ }^{11}$ Though the literature on trust suggests the rise in anonymity associated with urban growth ushered in more abstract and impersonal economic and social relations, Margot Finn has demonstrated that supposedly "premodern" forms of credit relations remained commonplace and widespread in England into the late nineteenth century. Though she challenges convincingly economic theory's "enduring misapprehension" that the cash nexus was the characteristic mode of modern market exchange, ${ }^{12}$ her depiction of the persistence of informal retail credit relations is useful when considering all retail transactions in this period, including those involving cash.

In this article, we seek to test some assumptions about social and economic relations in the late eighteenth and early nineteenth centuries by exploring ways that urban anonymity was negotiated by those making daily commercial transactions with strangers in what has been described as the "chaos and confusion of the early industrial city." 13 We do so by focusing on Britain's largest and arguably most impersonal urban center during a period when retailers appear to have been subject to growing risks in their day-to-day business, including the particular threat presented

\footnotetext{
${ }^{8}$ Shapin, Social History of Truth; Muldrew, Economy of Obligation, 5-7; James Taylor, Creating Capitalism: Joint-Stock Enterprise in British Politics and Culture, 1800-1870 (Woodbridge, 2006); Hannah Barker, "Medical Advertising and Trust in Late Georgian England," Urban History 36, no. 3 (2009): 379-98; Geoffrey Hosking, Trust: A History (Oxford, 2014), 105.

${ }^{9}$ Christel Lane, "Theories and Issues in the Study of Trust," in Trust within and between Organisations: Conceptual and Empirical Applications, ed. Christel Lane and Reinhard Bachmann (Oxford, 1998), 1-30.

${ }^{10}$ Francis Fukuyama, Trust: The Social Virtues and the Creation of Prosperity (Harmondsworth, 1995), 26-32. See also Georg Simmel, The Philosophy of Money, ed. David Frisby, 2nd ed. (London, 1990), 187; Lyn H. Lofland, A World of Strangers: Order and Action in Urban Public Space (New York, 1973), 22; Giddens, Consequences of Modernity, 92, 97; J. David Lewis and Andrew Weigert, "Trust as a Social Reality," Social Forces 63, no. 4 (1985), 967-85, at 969.

${ }^{11}$ Hoh-Cheung Mui and Lorna H. Mui, Shops and Shopkeeping in Eighteenth-Century England (Montreal, 1989); John Brewer and Roy Porter, eds., Consumption and the World of Goods (London, 1993); Craig Clunas, "Modernity Global and Local: Consumption and the Rise of the West," American Historical Review 104, no. 5 (1999): 1497-511; Maxine Berg, Luxury and Pleasure in Eighteenth-Century England (Oxford, 2007); Jon Stobart, Sugar and Spice: Grocers and Groceries in Provincial England, 1650-1830 (Oxford, 2012).

${ }^{12}$ Margot C. Finn, The Character of Credit: Personal Debt in English Culture, 1740-1914 (Cambridge, 2003), 5, 76-89.

${ }^{13}$ Lofland, World of Strangers, 56.
} 
by a rise in banknote forgery. Though a model of thick trust certainly fits neatly into an explanation of economic relations in the smaller towns of early modern England, the supposed shift to a society defined increasingly by thin forms of trust appears less compelling when examining the practices of late eighteenth and early nineteenthcentury London traders (who notably never used the terms trust or distrust in the sources used for this study in relation to unknown customers and their banknotes). Despite living in a city that bore many of the hallmarks of modernity in terms of population size, anonymity, and increasingly effective policing of banknote fraud, ${ }^{14}$ the capital's shopkeepers seem to have relied on decision-making processes that can appear poorly suited to the context of a society largely composed of broader, shallower networks of trust. Indeed, by consistently placing their faith in the local and the personal-even when the evidence presented to them seems extremely shakyand by relying on the knowledge or opinion provided by family and neighbors over and above that imparted by experts or institutions, the behavior of the capital's tradesmen and women can appear-superficially at least-as outdated and risky.

But rather than viewing the traders in this study as collectively misguided about the urban society in which they conducted their daily financial transactions, and blind to the levels of risk to which they exposed themselves, a close examination of their conduct suggests a different reading. Instead, we can explain the behavior of tradesmen and women as guided by alterative rationales, including individual calculation based on past and shared experience, a particular understanding of locality, and the wider context of institutional enforcement. ${ }^{15}$ By examining what happens to human interaction and social organization during one phase of the modern era, this study questions not just the utility of depending solely on trust as an explanatory concept in economic transactions but also the model of historical change on which many studies of trust and modernity are based. ${ }^{16}$ In doing so, and in common with other studies, it suggests that the process of social and economic change that accompanied the growth of towns did not involve Gemeinschaft neatly giving way to Gesellschaft 17 but was instead almost more complex and contradictory. ${ }^{18}$

We explore traders' responses to the risks of banknote forgery in the late Georgian period by examining reports of alleged uttering in shops and other trading

\footnotetext{
${ }^{14}$ McGowen, "Bank of England and the Policing of Forgery."

${ }^{15}$ Mark Granovetter, "Economic Action and Social Structure: The Problem of Embeddedness," American Journal of Sociology 91, no. 3 (1985): 481-510; Timothy W. Guinnane, "Trust: A Concept Too Many," Jabrbuch fuir Wirtschaftsgeschichte/Economic History Yearbook 46, no. 1 (2005): 77-92; McGowen, "Bank of England and the Policing of Forgery.”

${ }^{16}$ For example, Luhmann, Trust and Power; Giddens, Consequences of Modernity; Lofland, World of Strangers; Beck, Risk Society; Putnam, Bowling Alone; Uslaner, Moral Foundations of Trust; Zygmunt Bauman, Modernity and Ambivalence (Cambridge, 1991).

${ }^{17}$ Ferdinand Tönnies, Community and Society: Gemeinschaft und Gesellschaft, ed. and trans. Charles P. Loomis (New York, 1957).

${ }^{18}$ See, for example, Bruno Latour, We Have Never Been Modern, trans. Catherine Porter (Cambridge, MA, 1993); Nigel Thrift, "Not a Straight Line but a Curve,' or, Cities Are Not Mirrors of Modernity," in City Visions, ed. David Bell and Azzedine Haddour (Harlow, 2000), 233-63; Martin Daunton and Bernhard Rieger, introduction to Meanings of Modernity: Britain from the Late-Victorian Era, ed. Martin Daunton and Bernhard Rieger (Oxford, 2001), 1-21; Timothy Alborn, "Were the Victorians Ever Modern?," Journal of Victorian Culture 11, no. 1(2006): 154-60; Finn, Character of Credit; Deborah Valenze, The Social Life of Money in the English Past (Cambridge, 2006), 31-33; Karl Bell, The Magical Imagination: Magic and Modernity in Urban England, 1780-1914 (Cambridge, 2012).
} 
establishments in court records and newspapers between 1797, when the Bank Restriction Act was passed and new banknotes began to be issued, and the suspension of the Act in 1821. We draw upon other contemporary commentaries concerning fraud, deception, and the risks to traders, though such sources are comparatively scant compared to the materials located among the records of the Old Bailey, London's central criminal court. A search for the crimes of uttering and forgery located ninety-six trial reports that included 204 instances of alleged uttering involving the capital's traders. ${ }^{19}$ A search for similar reports in the Times identified an additional 130 examples involving tradesmen and women from across Britain, including many accounts from London magistrates' courts. Cases of alleged uttering and forgery are more poorly documented outside London. Though it is not hard to find newspaper reports of forged banknotes and their use from towns across Britain between 1797 and 1821, information outside London can be scant, even in terms of prosecutions. ${ }^{20}$ In 1809, a Times report on trials for uttering and forgery at the Lancashire Assizes stated that "from the late trials at Lancaster, it appears that a traffic in one, two, and five pound notes has existed for some time to a most alarming extent . . . and a witness stated that he had been assured by one of the prisoners, that at Birmingham he could buy forged small notes by wholesale enough to load a jackass." 21 Yet though reports of court proceedings suggested that prosecutions by the Bank of England might dominate whole days of court business, ${ }^{22}$ surviving court records provide little detail about specific cases. A study of the capital thus presents an opportunity to examine a phenomenon that was not restricted to London but where the details are more accessible than elsewhere in Britain.

Though a study of Old Bailey and newspaper records located 295 different instances of alleged uttering over a twenty-four-year period, there were at least twenty-three thousand shops in London alone in 1785, which does not immediately suggest that forged banknotes were a significant threat for retailers. ${ }^{23}$ However, the information provided by these two sources likely presents the tip of a much larger iceberg in terms of cases of uttering and the scale of banknote forgery, since these offenses are patchily documented in the main, with surviving reports largely restricted to cases in which the alleged culprits were both apprehended and appeared before a court. Randall McGowen's study of the policing of forgery by the Bank of England records only 2,131 prosecutions for forgery between 1797 and 1824, but it indicates that 259,369 forged notes were returned to the bank during the same

${ }^{19}$ In the Old Bailey sample, 197 individual banknotes were described; 42 percent $(83)$ were $£ 1$ notes; 9 percent $(17)$ were $£ 2 ; 25$ percent $(50)$ were $£ 5 ; 21$ percent $(42)$ were $£ 10$; and 3 percent $(5)$ were denominations of over $£ 10$. Where the issuing bank was mentioned, 83 percent were Bank of England notes, 17 percent "country" notes.

${ }^{20}$ Hiroki Shin, "The Bank of England Note outside London, 1797-1821," Business Archives, no. 92 (2006): 55-68. See, for example, Times, 18 October 1800; Times, 4 July 1801; Times, 1 February 1802; Times 5 October 1802; Times, 13 August 1813; Times, 17 September 1816; Times, 9 August 1817; Times, 24 October 1817; Times, 5 January 1818; Times, 9 April 1818; Times, 8 October 1818.

${ }^{21}$ Times, 31 August 1809.

22 Times, 5 September 1817.

${ }^{23}$ Figures of shops paying "shop tax" in 1785 covering London, Westminster, Southwark, and part of Middlesex; Mui and Mui, Shops and Shopkeeping in Eighteenth-Century England, 87. 
period. ${ }^{24}$ There was therefore good reason for contemporaries to believe that counterfeiting was both dangerous and pervasive-encouraging the Bank of England to expend considerable efforts on its policing, newspapers to carry frequent reports warning readers of the commercial risks it posed by publicizing individual crimes, and other publications aimed specifically at traders to urge caution. ${ }^{25} A$ Treatise on the Police of the Metropolis, for example, warned of "the fraud which is practiced upon shopkeepers, tradesmen, publicans, and others, through the medium of petty forgeries, by the circulation of copper-plate notes and bills for small sums, of $£ 5$ and $£ 10$ the latter purporting to be drawn by bankers in the manufacturing and seaport towns in London." 26 Published accounts of the lives (and unhappy ends) of forgers and utterers also alerted readers to the prevalence of forged banknotes, ${ }^{27}$ and sometimes handbills were delivered "house to house" in neighborhoods where counterfeit notes were suspected to circulate. ${ }^{28}$

The roots of the "counterfeiting crisis" of 1797-1821 are not difficult to trace. ${ }^{29} \mathrm{~A}$ shortage of gold during the wars against Revolutionary France in the late eighteenth century prompted the British government to suspend cash payments and the Bank of England in 1797 for the first time to issue banknotes of denominations below $£ 5$, a move that commercial banks quickly followed. A lack of specie had been common in England well before this period, ${ }^{30}$ and in some areas of the country, bills of exchange and tokens had been widely used for decades as an alternative to banknotes and coins. ${ }^{31}$ The issuing of $£ 1$ and $£ 2$ notes does not appear to have improved this situation significantly, but it did add a new layer of complexity for anyone involved in financial transactions, and traders in particular. The ease with which the new notes could be forged, coupled with their widespread use, provided much greater scope for criminal activity, especially forgery and uttering. ${ }^{32}$ The appearance of the new $£ 1$ and $£ 2$ notes-which, like notes of higher denominations, were printed in

${ }^{24}$ McGowen, "Bank of England and the Policing of Forgery," 87.

${ }^{25}$ McGowen, 87. See for example, The Troubles of Life; Being a Familiar Description of the Troubles of the Poor [... .] Shopkeeper (London, [1805?]); Crosby's Merchant's and Tradesman's Pocket Dictionary (London, 1808); The Honest Man's Guide, and Tradesman's Protector, Against the Frauds [. . . of the Various Kinds of Rogues [. . . That Infest London and Other Large Towns (London, [1820?]).

${ }^{26}$ A Magistrate, $A$ Treatise on the Police of the Metropolis, Explaining the Various Crimes and Misdemeanours Which At Present are Felt as a Pressure Upon the Community; and Suggesting Remedies for their Prevention [London, 1796], 146-47.

${ }^{27}$ See, for example, The Life and Singular Adventures of Jack Shepherd (London, 1787); An Authentic Account of Forgeries and Frauds of Various Kinds Committed by that Most Consummate Adept in Deception, Charles Price (London, 1786).

${ }^{28}$ Authentic Account of Forgeries and Frauds, 18-19.

${ }^{29}$ Philip Handler, "The Limits of Discretion: Forgery and the Jury at the Old Bailey, 1818-21," in "The Dearest Birth Right of the People of England": The Jury in the History of the Common Law, ed. John W. Cairns and Grant McLeod (Oxford, 2002), 155-72, at 160.

${ }^{30}$ T. S. Ashton, An Economic History of England: The Eighteenth Century (London, 1955), chap. 6; Muldrew, Economy of Obligation, 98-103; Valenze, Social Life of Money in the English Past, 34-50.

${ }^{31}$ B. L. Anderson, "Money and the Structure of Credit in the Eighteenth Century," Business History 12, no. 2 (1970): 85-101.

${ }^{32}$ Handler, "The Limits of Discretion;" McGowen, "Bank of England and the Policing of Forgery"; Hiroki Shin, "The Culture of Paper Money in Britain: The Bank of England during the Restriction Period, 1797-1821” (PhD diss., University of Cambridge, 2009); Jack Mockford, “'They Are Exactly as Banknotes Are': Perceptions and Technologies of Bank Note Forgery during the Bank Restriction Period, 1797-1821" (PhD diss., University of Hertfordshire, 2014). 


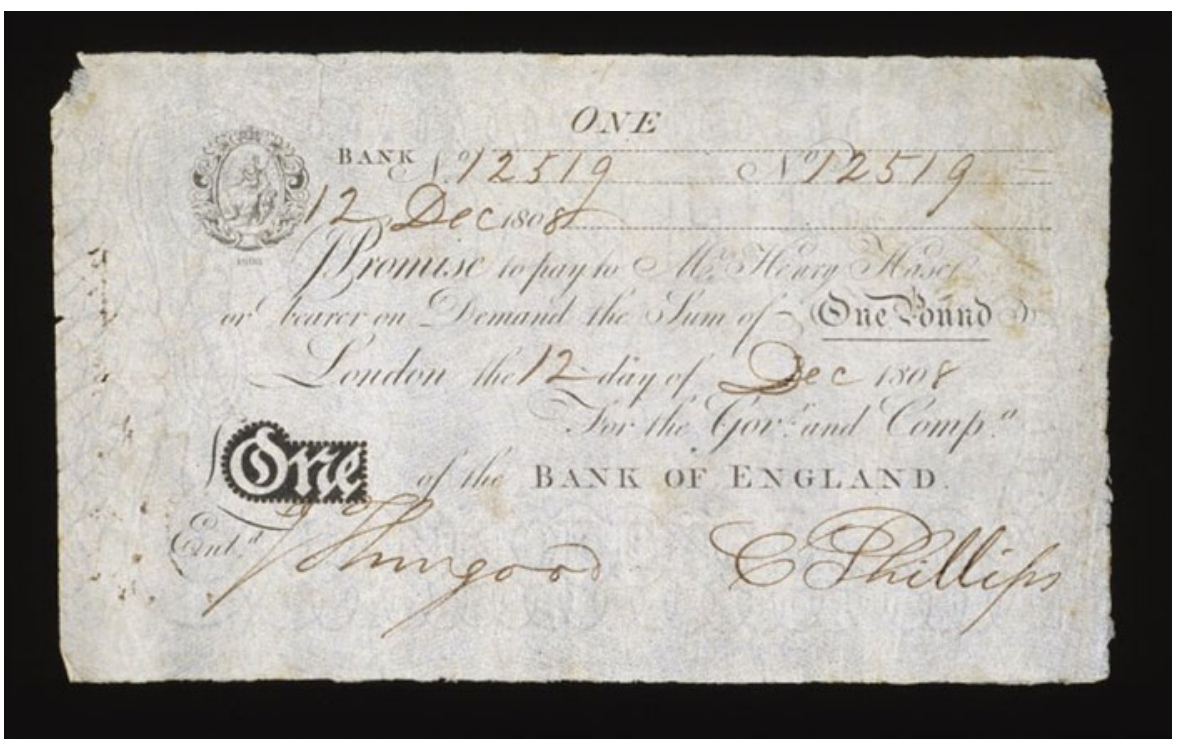

Figure 1-One-pound note, 1808, 20.5 x $12.2 \mathrm{~cm}, \mathrm{BM}$ 1980,1106.1, British Museum, (c) Trustees of the British Museum.

black ink on one side only of watermarked paper, with each note carrying an individual handwritten number accompanied by a bank clerk's dated signature-made them easy to counterfeit and for the unwary to be fooled. ${ }^{33}$ Genuine and forged banknotes could appear very similar, as evidenced by the examples in figures 1 and 2 (note that the "forged" stamps in figure 2 were added by Bank of England officials after the counterfeit was discovered). ${ }^{34}$

As was the case with bills of exchange and coinage, the ease with which notes could be convincingly counterfeited, coupled with the variety of legal tender produced by commercial banks across Britain, made it difficult for shopkeepers and small traders to distinguish the good from the bad. One response on the part of London traders was the formation in 1776 of the Society for the Protection of Trade Against Swindlers and Sharpers as a means of supporting legal prosecutions against fraudulent debtors and of sharing information about individuals with poor credit and the circulation of forged financial instruments. ${ }^{35}$ The organization's membership was dominated by retailers, small-scale manufacturers, and service providers such as coffeehouse keepers, grocers, and drapers. Members received printed circulars proclaiming the names and addresses of individual traders with poor credit and information concerning counterfeit bills of exchange and particular banknotes that ought not

\footnotetext{
${ }^{33}$ Virginia Hewitt, "Beware of Imitations: The Campaign for a New Bank of England Note, 17971821, Numismatic Chronicle, no. 158 (1998): 197-222.

${ }^{34}$ We are grateful to the kind assistance of Eleanor Paton of the Bank of England Museum in locating examples of forged banknotes in their collection. We thank the Bank of England for permission to reproduce their images in this article.

${ }^{35}$ Finn, Character of Credit, 289-94.
} 


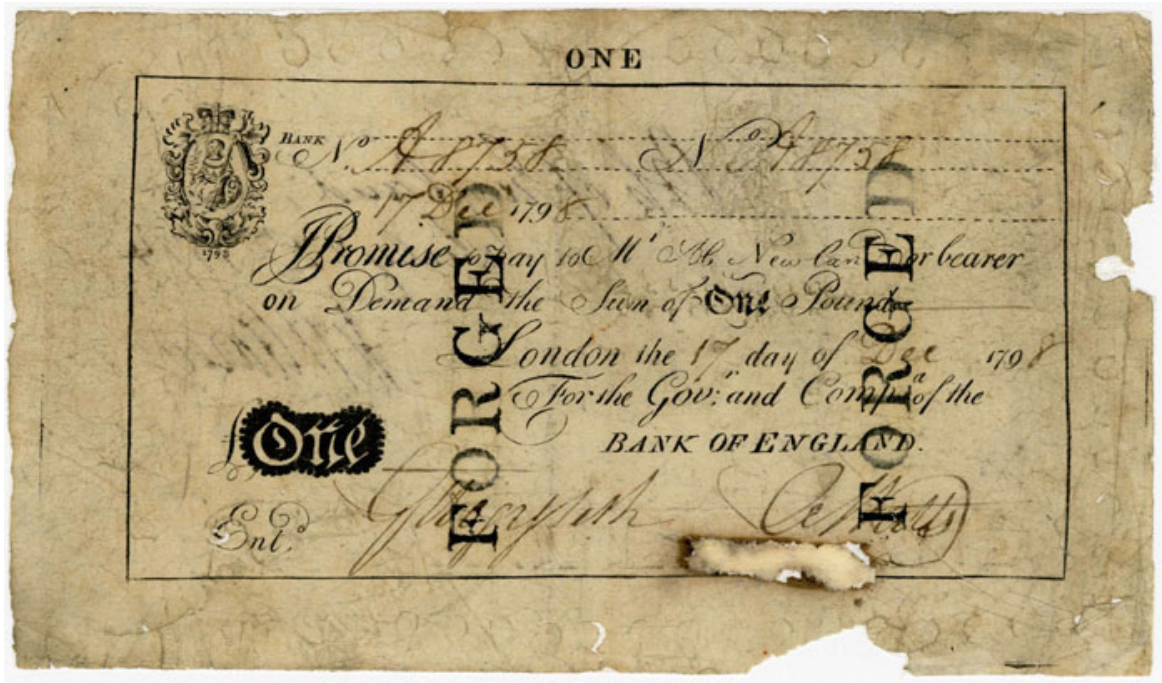

Figure 2-Forged one-pound note, presented to the Bank of England on 5 February 1811, $18 x$ $10.5 \mathrm{~cm}, \mathrm{S4} / 001 \mathrm{~B}$, Bank of England Museum.

to be trusted (for example, since the bank was no longer trading). Occasionally the society's circulars provided information concerning individuals accused of passing forgeries to traders. An 1825 circular, for example, cautioned against a pair who presented a forged bill of exchange "dated Sheffield" and redeemable from "Messrs Bosanquet and Co." The individuals involved in the scam were said to be a "dashing lady" traveling with a man calling himself George Watson, who was "of middle stature, about 30 years of age," and with "a plausible quick address." 36 The anonymous author of the circular, titled The Swindler Detected: Or Cantion to the Public, was dismissive of the society and suggested that its way of working "is by no means sufficient, because it does not protect the merchant, or shopkeeper, from losing his property; it is only a method of bringing the offending party to justice." The author promised instead to provide readers with descriptions of "the various methods by which the swindler and sharper obtains possession of their property of the honest, and undesigning tradesman" in the hopes that "he may be able to guard against every species of fraud and imposition." 37 Yet the pamphlet seems to have relied on readers' working out methods of identifying frauds themselves, for though it contained descriptions of different types of deception, it did not provide specific advice on how to tell an honest customer from one who was not, nor how to distinguish a forgery from the genuine article.

The Rev. Dr. Trusler devoted several pages of his London Adviser and Guide to warnings on how to avoid "robberies, frauds, impositions and insults," but though

${ }^{36}$ Miscellaneous Correspondence and Papers, Society of Guardians for the Protection of Trade Against Swindlers C114/34 (1825-27), National Archives (UK).

37 The Swindler Detected: Or Cautions to the Public: Containing a Minute Account of the Various Frauds and Impositions Practised on the Honest and Industrious Tradesmen of this Metropolis (London, 1781), 1-2. 
he specifically noted that those in trade should "be cautious how you are taken in by customers you are a stranger to" and should watch out for "sharpers" who often had a "genteel appearance," he, too, provided no specific advice about how to exercise the caution that was needed nor the best way to avoid being defrauded. ${ }^{38}$ The authors of the London Tradesman (1819) did add more detail in this respect-tradespeople should be suspicious of individuals with "an earnestness somewhat strained or overcharged; a kind of febrile affection, that savours too much of interestedness in obtaining belief; and which shows itself not only in loud tones and high sounding pretensions, but also in a hundred repetitions, in vehement gesticulation, and in uneasiness of posture"-but the advice was unlikely to have been foolproof. ${ }^{39}$ The difficulties of judging by appearances did not decline during the decades that followed. J. H. Elliott, author of Credit in the Life of Commerce, published in 1845, claimed that the difficulty of judging the character of either individuals or banknotes, especially from appearances alone, placed tradespeople in an impossible situation in everyday financial dealings. "A bank-note has a good character when it has certain appearances," he observed, "but it may be a forged one nonetheless. To have a good character and to deserve it are two very different things indeed." 40

The trial of Thomas Edwards, a journeyman silversmith from London accused of uttering in 1804, shows both the dangers of forged notes to the unwary and the ease with which they could be passed to other apparently unwitting traders. Edwards was accused of knowingly passing forged $£ 2$ notes to several retailers. His deposition at the time of his arrest stated that he had received the notes from a man he met in Clerkenwell as payment for the manufacture of several silver boxes. Edwards freely admitted using them to buy goods at a number of shops: "I paid one to a pork-shop, in Fleet-market; I paid one at Jenkins's, a pawnbroker, in Redcross-street, where I redeemed some silver boxes; last week, at the beginning, I paid one to redeem six silver tea-spoons, in Shoreditch; two ladies keep the shop, left hand side, near the bottom of Old-street; about three weeks ago today, I paid another in Holborn, Middle-row, near Brook-street; bought a pair of shoes and gaiters.” According to his account, it was not until he went to the shop of a Mr. Spinks in Barbican and presented one of the notes for payment that he was "told it was a bad one."41

Edwards's defense rested on his lack of guilty knowledge: "I am a young man," he protested, "and have not been taught that caution which the Counsel against me seems to think I ought to be in the possession of." Similarly, when Charles Linsey was accused of trying to pass a forged note in a butcher's shop in 1799, he claimed that the note had been taken by his wife from a customer in their own shop, "which any tradesman here might do; I suppose a number of gentlemen on the Jury entrust their wives in their shops, and I hope they will feel for my situation;

${ }^{38}$ Rev. Dr. Trusler, The London Adviser and Guide: Containing Every Instruction and Information Useful and Necessary to Persons Living in London, and Coming to Reside There (London, [1786]), 150-51.

39 The London Tradesman: A Familiar Treatise on the Rationale of Trade and Commerce (London, 1819), 103.

${ }^{40} \mathrm{~J}$. H. Elliott, Credit the Life of Commerce: Being a Defence of the British Merchant against the Unjust and the Recent Alterations in the Laws of the Debtor and Creditor (London, 1845), 103-4.

${ }^{41}$ Trial of Thomas Edwards, 11 April 1804, t18040411-52, OBP, https://www.oldbaileyonline.org/ browse.jsp? div $=$ t18040411-52. 
it is impossible for them to tell a good note from a bad one."42 Other tradesmen and women giving evidence in court were-unlike the unfortunate Edwards and Linsey -more likely to stress that they had taken reasonable care when accepting banknotes, especially from strangers. But just how cautious individuals were expected to be and what forms of taking care were seen as reasonable were not clear-cut. Nor can we always believe traders' assertions about the level and forms of caution that they exercised, for in order to protect themselves from censure, they were likely to claim that they had acted responsibly and taken every reasonable care. ${ }^{43}$ Moreover, as Robert Shoemaker has cautioned, we must be wary of assuming that Old Bailey proceedings were full or entirely accurate accounts of what happened in court, while the motivations of those creating the records of proceedings might have further colored what was recorded. ${ }^{44}$ Yet despite these significant caveats, the reasons presented for retailers instituting certain checks, or their claims to have done so, were not randomly invented, and we know from Shelley Tickell's study of shoplifting in this period that retailers routinely expended considerable effort to enact a variety of measures to prevent theft. ${ }^{45}$ Though court records reveal a range of practices reflecting differing ideas about what constituted reasonable care and various ways traders gauged when to accept banknotes from strangers, certain habits of behavior (or alleged behavior) stand out and are repeated again and again. From this, we can have some confidence in judging normative behavior from the evidence of court records. Moreover, Edwards's comment reminds us that caution in economic transactions was something that needed to be learned. This process of learning-especially from one's family, employers, and peers-might go some way to explaining the common patterns we see among tradespeople involved in cases of alleged uttering. ${ }^{46}$

One frequently remarked-upon aspect of the growth of towns and rise of anonymity was the ability to assume a particular social status or to "pass" simply by virtue of one's dress and demeanor. This was something that both contemporaries and historians have noted, with the phenomenon often presented as striking because of the apparently flimsy basis on which such judgments depended. ${ }^{47}$ Making assessments

42 Trial of Charles Linsey, 19 June 1799, t17990619-20, OBP, https://www.oldbaileyonline.org/browse. jsp?div=t17990619-20; Times, 24 June 1799.

${ }^{43}$ Luhmann, Trust and Power, 26. On assessing witnesses statements in court records, see Natalie Zemon Davis, Fiction in the Archives: Pardon Tales and Their Tellers in Sixteenth-Century France (Cambridge, 1987), 20-25; Hans-Joachim Voth, Time and Work in England, 1750-1830 (Oxford, 2000), 23-40; Joanne Bailey, "Voices in Court: Lawyers' or Litigants'?, Historical Research 74, no. 186 (2001): 392-408; Katie Barclay, "Narrative, Law and Emotion: Husband Killers in Early Nineteenth-Century Ireland," Journal of Legal History 38, no. 2 (2017): 203-227; Amy Milka, "Feeling for Forgers: Character, Sympathy and Financial Crime in London during the Late Eighteenth Century," Journal for Eighteenth Century Studies 42, no. 1 (2019): 7-25.

${ }^{44}$ Robert Shoemaker, "The Old Bailey Proceedings and the Representation of Crime and Criminal Justice in Eighteenth-Century London," Journal of British Studies 47, no. 3 (2008): 559-80.

${ }^{45}$ Shelley Tickell, "The Prevention of Shoplifting in Eighteenth-Century London," Journal of Historical Research in Marketing 2, no. 3 (2010): 300-13; Shelley Tickell, "Shoplifting in Eighteenth-Century England" (PhD diss., University of Hertfordshire, 2015).

${ }^{46}$ Hannah Barker, Family and Business during the Industrial Revolution (Oxford, 2017), 97-126.

${ }^{47}$ P. J. Corfield, The Impact of English Towns, 1700-1800 (Oxford, 1982), 124; Peter Borsay, The English Urban Renaissance: Culture and Society in the Provincial Town, 1660-1770 (Oxford, 1989), 225-41; Burke, "Imagining Identity in the Early Modern City;" Robin Pearson, "Moral Hazard and the Assessment of Insurance Risk in Eighteenth- and Early-Nineteenth-Century Britain," Business History Review 76, no. 1 
on the basis of appearance and behavior seems to have been commonplace among traders accepting banknotes from strangers in late eighteenth- and early nineteenth-century London. Indeed as Finn has noted, determining individual character and credit during all types of financial exchanges in this period "rarely reflected precise knowledge of individual wealth." 48 Contemporary commentators and newspaper reports often noted the respectable appearance of suspected utterers, suggesting that a genteel demeanor made an individual more likely to appear trustworthy. The author of $A$ Treatise on the Police of the Metropolis, for example, observed, "The great quality, or leading and indispensable attributes of a Sharper, a Cheat, a Swindler, or a Gambler, is to possess a genteel exterior, a demeanor apparently artless, and a good address." ${ }^{\prime 9}$ The Times reported on 11 March 1820 that Charles Ross, who had appeared before the Bow Street magistrates in London accused of passing forged notes, was "a young man of highly respectable connexions"- and was "well qualified" to commit such frauds "from the general liberal education he had received, as well as his genteel appearance and accomplished manners." 50 Yet the same paper described a William Johnson, "alias Wise," whose "method of passing the notes was at once bold and ingenious," for while he sometimes dressed and acted as a gentlemen, he seems to have been equally successful in other guises, not all of which suggested wealth or gentility. Johnson was said to have passed "two notes in one day to Mr. Cooper, a publican, in Golden-lane, with whom he was a gentleman's servant. In an hour or two after he was at Lamb-street, Spitalfields, he was one of the Dandies of the day; soon after as a servant in livery, and lastly as a country bumpkin; and in each case he proved successful." ${ }^{51}$ Johnson's skill, it seemed, was in seeming to be genuine and honest in various guises rather than simply appearing wealthy.

Behaving as if one is not a fraudster but an honest citizen - putting on a believable front-is of course what successful fraudsters have always done. ${ }^{52}$ Judging the trustworthiness or reliability of strangers by their appearance and conduct was a process that usually involved traders making a number of assessments within a relatively short time, based on limited evidence. The behavior of some would-be utterers made this process easier for John Clarke, a waiter at the Blenheim coffeehouse on Bond Street, who raised the alarm about William Stanford, whom he noticed not only "had a dirty shirt on, which did not look like a gentleman," but also passed written notes at the table to his companion, one note instructing him to drink

(2002): 1-35, at 2-3; Hoppit, "Use and Abuse of Credit," 73; Ulinka Rublack, Dressing Up: Cultural Identity in Renaissance Europe (Oxford, 2010), 265-70.

${ }^{48}$ Finn, Character of Credit, 21, 280-89.

${ }^{49}$ Magistrate, Treatise on the Police of the Metropolis, 146-47.

50 Times, 11 March 1820. See also Times, 6 November 1817; Times, 17 September 1816; Times, 11 February 1820; Times, 7 March 1820; Times, 14 September 1820; Times, 14 July 1821.

${ }^{51}$ Times, 11 March 1820.

52 Stephen Mihm, A Nation of Counterfeiters: Capitalists, Con Men, and the Making of the United States (Cambridge, MA, 2007); Tobias B. Hug, Impostures in Early Modern England: Representations and Perceptions of Fraudulent Identities (Manchester, 2009). On the use of similar conduct and arguments in the courtroom, see Anna Field, "Coining Offences in England and Wales, c. 1675-1750: The Practical and the Personal," Cultural and Social History 15, no. 2 (2018): 177-96; Milka, "Feeling for Forgers," 15-18. On "front" and "passing," see also R. E. Park, "The City: Suggestions for the Investigation of Human Behaviour in the Urban Environment," in The City, ed. R. E. Park, E. W. Burges, and R. D. McKenzie (Chicago, 1925), 1-46; E. Goffman, The Presentation of the Self in Everyday Life (New York, 1958). 
more slowly. In contrast, earlier at a nearby jewelers shop, the shopman Thomas Connelly described the same man, William Stanford, offering him a banknote which "on first sight I thought . . . was bad. However I examined it very minutely, and saw it was more perfect than many I had seen, and from that, and his genteel appearance, I was induced to take it." 53

Judging by appearances was a risk, but it was only one way that traders had to assess whether or not to accept banknotes from unknown individuals, as Thomas Connelly's description of his examination of both the alleged utterer and his banknote suggest. Though James Boswell famously claimed to have been able to walk out of a London shop in 1762 in possession of a valuable sword, with the shopkeeper willing to advance him credit based solely—according to Boswell—on his "external appearance and address," an important detail in this story that is less commonly recounted is that the shopkeeper also asked the "stranger" Boswell for his "name and place of abode" before letting him depart with the goods. ${ }^{54}$ At that time, Boswell was lodging in Downing Street, less than half a mile from the Strand where he obtained the sword. ${ }^{55}$ The closeness of this address would have been important. This practice of asking unfamiliar customers for a name and address was extremely common, as was accepting banknotes from strangers because they lived-or claimed to live-locally. Such was the weight attached to proximity that witnesses in 68 percent of the Old Bailey sample noted that unknown customers had claimed to live near to the shops where they were accused of uttering. The practice of writing a customer's name and address on the back of a banknote was frequently mentioned in court cases, and a few surviving banknotes - such as the example in figure 3-display this practice.

Though it is not surprising that shopkeepers in late Georgian London frequently accepted banknotes from individuals, households, and businesses with whom they had extensive knowledge and established relationships, what is less expected is that they would do the same for strangers based on unsubstantiated assertions, or their own assumptions, that they were linked to these same networks, especially when the evidence for this appeared thin or nonexistent. Although, as has been noted, we should be wary of accepting without question the explanations that traders gave to the courts, for they were trying to defend their own behavior in public, it is clear that their testimony followed familiar patterns that privileged the local over the distant, especially in terms of relationships with neighbors and established clientele. Thus the Clerkenwell cheesemonger James Benson claimed to have accepted a $£ 10$ Bank of England note from Cornelius Holt in 1800 because Holt appeared to know another more familiar customer, a Mr. Amphlet, with whom he was seen speaking. Benson stated that though Holt was a stranger to him, "I knew Mr. Amphlet, and took him to be a friend of his that made me give change." $" 56$ Retailers might also choose to take notes presented by strangers who claimed to be acting on behalf of individuals that they knew and whose credit was established, again with little or no proof that the relationship existed. The London butcher William

\footnotetext{
${ }^{53}$ Trial of William Henry Stanford, 12 April 1820, t18200412-116, OBP, https://www.oldbaileyonline. org/browse.jsp?div=t18200412-116.

${ }^{54}$ James Boswell, London Journal, ed. F. A. Pottle, 2nd ed. (Edinburgh, 2004), 60.

55 Boswell, London Journal, 53, 59-60.

${ }^{56}$ Trial of Cornelius-Frederick Holt, 9 July 1800, t18000709-103, OBP, https://www.oldbaileyonline. org/browse.jsp?div=t18000709-103.
} 

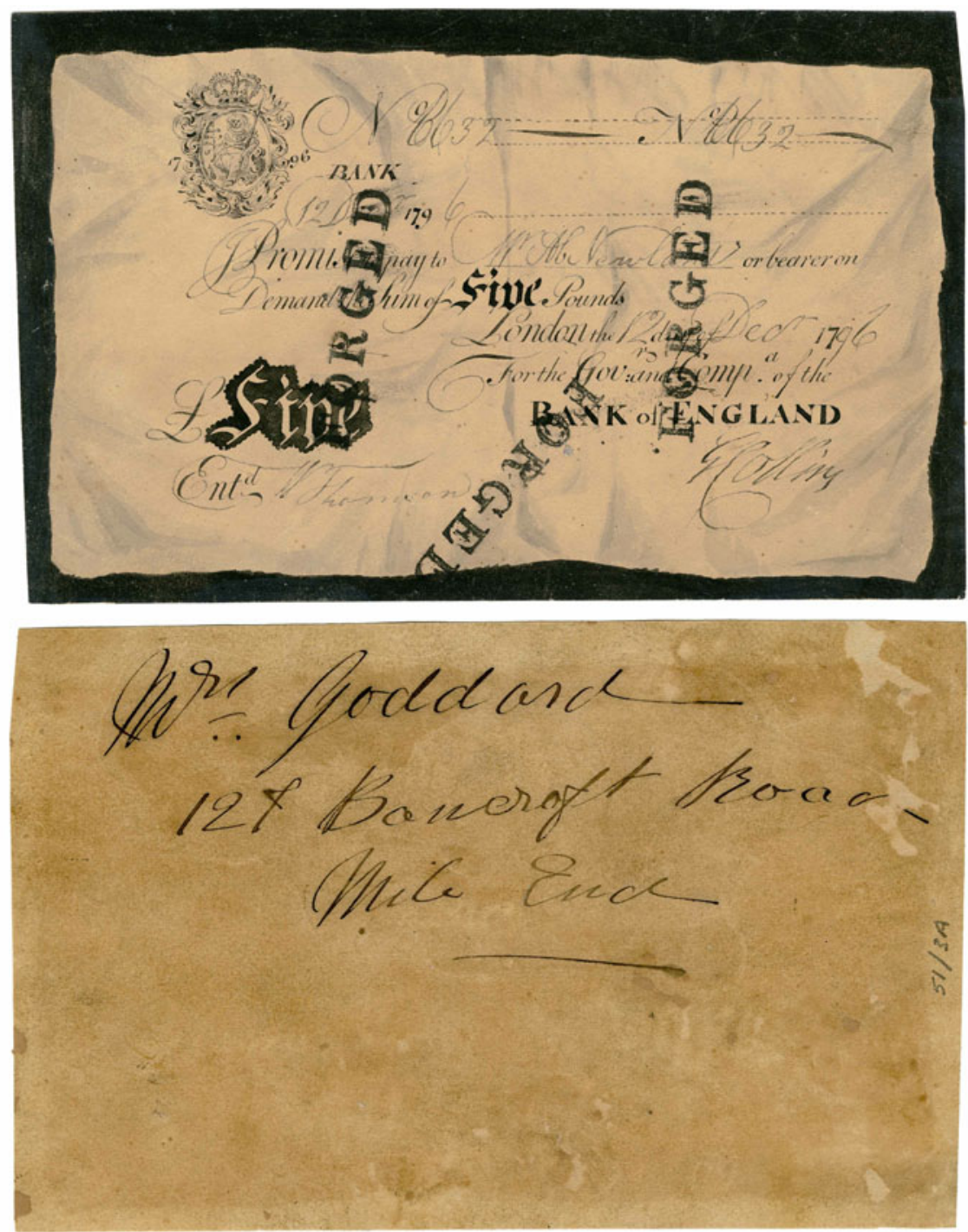

Figure 3-Obverse and reverse of forged Bank of England five-pound note, $20.7 \times 13 \mathrm{~cm}, S 1 / 003 \mathrm{~A}$, Bank of England Museum.

Ortman reported that he had given John Hindes change for a five guinea Yarmouth banknote because he had said he was buying meat on behalf of an existing customer. Ortman told the court, "He told me he lived with one Mr. Atkinson, in Park-street," noting ruefully that it later became apparent "that was not true." 57 William Ward, a

57 Trial of John Hindes, 12 July 1797, t17970712-56, OBP, https://www.oldbaileyonline.org/browse. jsp?div $=\mathrm{t} 17970712-56$. 
grocer of Fish Hill Street, accepted Joseph South's claim to be acting on behalf of an existing customer, Mr. Reily of Finsbury, apparently despite suspicions about the banknote that South presented. Ward stated in court that "I took it in my hand, and thought it was forged; I sent it to a neighbour by John Maylard, my shopman, he returned, brought it with him, and said in his presence, that it was forged-I then asked him [South] particularly if he came from Mr. Reily, he said 'Yes'; and I thought his story so good, that I believed him." 58

A Mr. Bavistock, a publican of Price's Street, Barbican, appears to have been equally convinced that a customer was closely linked to someone he knew when he accepted a $£ 10$ counterfeit note from Henry Locke even though his wife "at first demurred to change a check for a stranger." But after Locke said that he was acting on behalf of "their neighbor, Mr. Richards, in Bridgewater-square, whose men were waiting for payment," Bavistock described himself as being "desirous to oblige him, as a neighbor and a customer." Among the complex set of calculations that Bavistock and others had to make when deciding whether or not to accept banknotes from strangers such as Locke was the desire not to offend or inconvenience an established local contact. This was an important consideration in a commercial world where economic survival depended on local networks and trading relationships. The court hearing Bavistock's testimony was also told, "Neither the witness nor his wife had any doubts of the prisoner's person," not just because he claimed to represent their neighbor but also because Richards recognized Locke and "had seen his face frequently, but could not at first tell where."59 Facial recognition was commonly given as a reason for accepting banknotes, even when nothing else was known about individuals or their creditworthiness, because it suggested a familiarity borne out of proximity. Jeremiah Boke, the servant of Mr. Porter, a linen draper of Cranbourne Alley in London, accepted a $£ 5$ Suffolk and Essex banknote from Joseph Jemmett because he knew him "Perfectly well," having seen him "half-adozen times before" in the shop; yet Porter admitted that he knew nothing else about Jemmett, including "what trade or business he was in."60 Similarly, Matthew Green, a "tailor and salesman" on the Edgeware Road, accepted a $£ 1$ note from William Messenger on the basis that his daughter said "she had seen him many times."61 Among the Old Bailey sample of instances of alleged uttering, 13 percent of cases concerned strangers who either claimed or appeared to know someone local who was also known to the trader, and 12 percent involved shopkeepers asserting that they accepted the banknote presented by an individual simply by virtue of recognizing their face: yet in almost all of these cases (87.5 percent) they could not put a name to the face. Both these tendencies demonstrate the importance of the local for retailers and their reliance on neighborhood connections in deciding whether customers and their banknotes were genuine.

\footnotetext{
${ }^{58}$ Trial of Joseph South, 24 October 1821, t18211024-51, OBP, https://www.oldbaileyonline.org/ browse.jsp? div=t18211024-51.

59 Times, 20 August 1808.

${ }^{60}$ Trial of Joseph Jemmett, 16 February 1803, tl8030216-48, OBP, https://www.oldbaileyonline.org/ browse.jsp? div =t18030216-48.

${ }^{61}$ Trial of William Messenger, 14 February 1821, t18210214-41, OBP, https://www.oldbaileyonline. org/browse.jsp?div=t18210214-41.
} 
John Adams was one of the more prolific utterers to make use of shopkeepers' inclination to accept banknotes presented by strangers if they appeared to be linked to someone with an established local reputation. Adams was accused in 1818 of defrauding several grocers in and around Covent Garden by presenting them with forged notes and by pretending to have been sent by neighboring coffeehouse owners. George Hopkinson, a tea-dealer and grocer based on Henrietta Street, said that Adams had visited his shop "dressed as a porter" and asked for "a pound of 8 s. black tea for Mr. Robinson, of Monday's Coffee-house.” Presumably to add an additional inducement for Hopkinson, Adams told him that "Mr. Robinson sent him for the tea on trial, and if he liked it he would have more of it." Hopkinson claimed to have been convinced by Adams, and stated that he did not suspect the note until it was returned by his bank after he had tried to pay it into his account. Another grocer, Matthew Showsmith, of St. Martin's Lane, recalled that Adams "came to my shop, and asked me if I knew Mr. Godfrey, of the Rainbow Coffeehouse? I told him I did. He asked me if I had seen him that evening? I said I had not. He looked round the shop, turned round again, and said, this must be the shop, and asked for a pound of $8 \mathrm{~s}$. tea, I served him; he then tendered me a 5 1. note-I wrote Mr. Godfrey's name and address on it." When asked why he did this, Showsmith replied that "he asked for the tea for him, and I served him; he then told me to put the price of the tea on the paper, and put paid, as Mr. Godfrey was very particular-I knew Mr. Godfrey was particular, and had his things done in that way." A similar tale was told by Valentine Blencowe, who worked for Messrs. Yockneys, grocers and tea-dealers on Bedford Street: "On the 19th of November, about seven o'clock in the evening, the prisoner came to my master's shop, dressed as a porter, and asked for a pound of tea for New Slaughter's Coffee-house; it came to $8 \mathrm{~s}$., I served him; he tendered me a 5 l. note, I wrote Mr. Ruddel, Slaughter's Hotel. . . and gave him the change." Another grocer, John Barclay of St. Martin's Lane, was also asked for a pound of $8 \mathrm{~s}$. black tea by Adams "dressed as a porter," who claimed on this occasion to be acting for a Mr. Wells of Northumberland Coffee-house, Charing Cross. This time, a forgery was suspected from the appearance of the note, despite Adam's calm and convincing manner, which had helped him carry out earlier transactions with ease. Barclay's suspicion about the note meant that he "sent my young man, George Rose, down to Mr. Wells to know if he had sent a person for a pound of tea." At this point Adams fled. On giving evidence, the coffeehouse keeper, John Wells, asserted that he "was never my porter-I did not send him to buy any tea, or give him a $5 \mathrm{l}$. note for any purpose whatever." He noted, however, that "I know him by sight; I believe he worked at Old Slaughter's Coffee-house, St. Martin's-lane, when I was waiter there." 62

Adams was clearly a convincing fraudster in part because his knowledge of the coffeehouses in one small area of London made local shopkeepers believe that he was acting on behalf of others whom they either knew or whose local credit and reputation was widely recognized. Some, like John Wells, may also have found his face familiar, even if they could not place him. All the establishments that Adams either

${ }^{62}$ Trial of John Adams, 13 January 1819, t18190113-41, OBP, https:/www.oldbaileyonline.org/ browse.jsp? div $=t 18190113-41$. 
visited or claimed to represent were within a small radius of each other, between about 300 and 400 meters (328-437 yards) apart. Appearing to be a local by displaying specific knowledge of neighboring coffeehouses and their owners no doubt added veracity to his claims to be representing nearby businesses, since shopkeepers might expect a significant proportion of their customers to come from the surrounding area. But the preference for the local over the distant among retailers was also apparent in other cases involving forged notes, as we have seen, when confidence appears to have been secured simply by claiming to live locally, with little evidence of local knowledge apart from a street name. Supplying a name and a local address seems to have been enough to reassure a significant proportion of tradespeople who became embroiled in uttering cases. Thus, though John Fowler, shopman to a Mr. Jones of 7 Cow Lane, admitted to having suspicions about a $£ 1$ note presented to him by Sarah Whiley and Ann Haynes in 1804, he reported in court, "I agreed to take the note upon these terms, if they would tell me where they lived." He claimed to have been satisfied enough to accept their note when told they lodged in a nearby street, asserting that he did not discover that the note was "bad" until a week later. ${ }^{63}$ Similarly, grocer William Tomlin, whose shop was at 142 Tottenham Court Road, asserted that he accepted a $£ 1$ note from Mary Best not just because he thought he recognized her as a recent customer but also because his request for a name and address to put on the note resulted in her providing a local address. Tomlin later stated in court that "that place not being above half a quarter of a mile from my house I did not scruple of taking the note at all." 64

The ease with which an unknown customer could elicit the confidence of shopkeepers simply by convincing them that they lived locally is clearly illustrated by the case of Harriet Skelton, who was charged with uttering at shops across London in 1818. Thomas Ragless, a confectioner at 198 Piccadilly, testified that Skelton entered his shop to buy a 10 s. 6 d. twelfth-cake 65 and offered him a $£ 5$ note: "I asked her what address I was to put on it? she gave me the name of 'Moore, No. 29, Bury-street, St. James's." No doubt to test her, Raglass claimed, "I told her I knew a person of the name of Moore, at No. 5, and asked her if she had not made a mistake? she said, No; she lived at No. 29, Bury-street, and repeated the name and number several times over.” Such apparent certainty on Skelton's part seems to have been enough to convince Raglass to complete the transaction. Another confectioner, Richard Sewell of Titchfield Street, reported a similar story but this time with Skelton supplying a different name and address. He described her presenting a $£ 5$ banknote in payment for a twelfth cake. "Before I gave her change," he claimed, "I asked her to favour me with her address-She gave me the name of 'Wise, No. 11, Golden-square,' which I immediately wrote on the note, in her presence." Upon cross-examination, he stated, "I had no suspicion of the prisoner," although he noted, "I had never seen her before." James Malley, shopman to the

\footnotetext{
${ }^{63}$ Trial of Sarah Whiley and Ann Haynes, otherwise Foss, 11 April 1804, t18040411-50, OBP, https:// www.oldbaileyonline.org/browse.jsp?div $=$ t1804041 $1-503$.

${ }^{64}$ Trial of Mary Best, 13 May 1812, t18120513-20, OBP, https://www.oldbaileyonline.org/browse.jsp? $\operatorname{div}=\mathrm{t} 18120513-20$.

65 "A large cake used at the festivities of Twelfth-night, usually frosted and otherwise ornamented, and with a bean or coin introduced to determine the 'king' or 'queen' of the feast." OED Online, s.v. "twelfthcake," accessed 9 October 2018, www.oed.com.
} 
clothes salesman Mr. Swift of Houndsditch, also accepted a $£ 5$ note from Skelton; he told the court, "I asked her name and address, she gave me the name of 'Mrs. Jackson, No. 32, London Wall' which I wrote on the note, and gave her change." Susannah Waller, who ran a linen drapers in Aldgate with her husband, John Waller, also took a $£ 5$ note and gave change for 18 s worth of goods. Her shopman, James Grigg, endorsed the note with the name and address Skelton supplied: "Jackson, 76, Whitechap[el]', before it was put into the till." Mrs. Waller confirmed that Skelton "was a stranger." Grocer William Poole of Golden Lane, Barbican, accepted a $£ 1$ note from Skelton for "some things, which came to 3 s. or 4 s. . . . I asked her for her name and address-She gave me 'Mrs. Atkins, No. 12, Mitchell-street, Brick-lane,' which I wrote on the note. . I gave her the change. I have tried to find out such a person, but cannot." Another confectioner, George Howard, of 36 Princes Street, Soho, described how Skelton "bought a few cakes, and a quarter of a pound of ratifias 66 She tendered a 11. note in payment. I asked her for her address-She said, 'Mrs. Jones, Windmill-street,' which I wrote at the bottom of the note."67

When mapped, the relationship between the addresses that Skelton gave as her places of residence and the shops that she visited forms a clear pattern (figure 4). Each address was between two hundred and eight hundred meters (219-875 yards) from each shop: not so near as to be on the retailers' doorsteps so that they would expect to recognize them or could check on the address quickly but near enough to be local. Skelton's effective pretense to live locally seems to have depended on her persuasive manner and her deciding on a different and appropriate address for each shop she visited. By convincingly situating herself within the shopkeepers' neighborhoods, she was able to present herself as a stranger who was nevertheless a member of that community and whose person and money were therefore creditable.

Joseph Kimbell, who worked at Mr. Peckham's inn, displayed similar reasoning linking locality with trustworthiness in 1804 when Thomas Bucknell presented him with a $£ 1$ note for the ale and tea that he had consumed with his companions. Kimbell accepted the banknote on the condition that Bucknell wrote his name and address on the back of it, reporting later that "he wrote on it William Humphrys, Charlton-street; I only made mention to him, that he was a near neighbour; and he said, yes, meaning that it was the same street that we lived in; he gave me his address, No. 14, or 17, in that street." When asked in court "You took the note upon that?" Kimbell replied, "Yes; upon his signifying it, and gave him change for it." 68 Here Kimbell appears to have relied not just on being given a name and address but also on a signature as an additional form of proof. As Natasha Glaisyer has shown, the signature was a "widely understood mark of trust and a guarantee that paper credit could be relied upon." 69 Indeed, banknotes all carried the handwritten

\footnotetext{
66 "Ratafia essence, typically extracted from almonds or the kernels of cherries, apricots, and peaches, was used to flavour small cakes or biscuits." OED Online, s.v. "ratafia," accessed October 2018, www. oed.com.

${ }^{67}$ Trial of Harriet Skelton, 18 February 1818, t18180218-65, OBP, https://www.oldbaileyonline.org/ browse.jsp?div $=\mathrm{t} 18180218-65$.

68 Trial of Thomas Bucknell, 4 July 1804, t18040704-17, OBP, https:/www.oldbaileyonline.org/ browse.jsp?div=t18040704-17; Times, 6 July 1804.

${ }^{69}$ Natasha Glaisyer, "Calculating Credibility: Print Culture, Trust and Economic Figures in Early Eighteenth-Century England,” Economic History Review 60, no. 4 (2007): 685-711, at 709.
} 


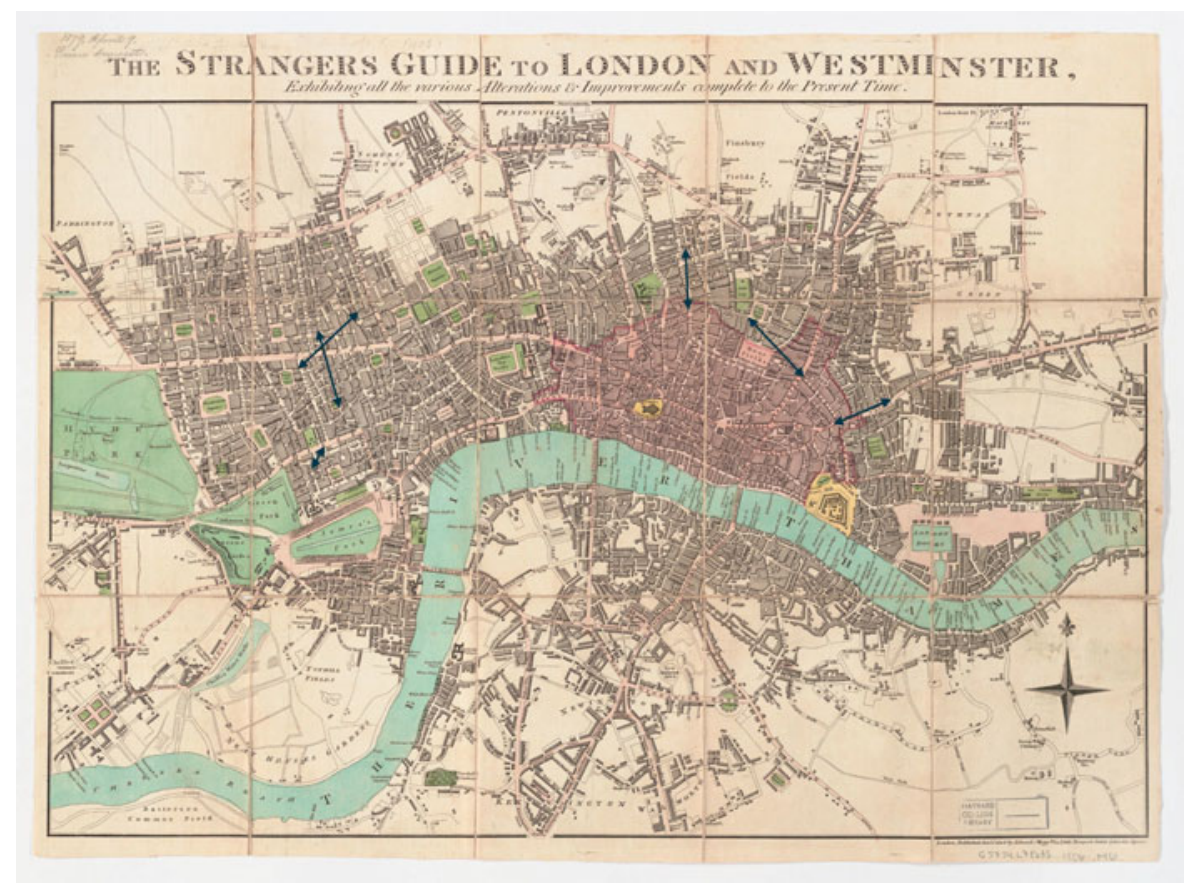

Figure 4-Harriet Skelton's 1818 uttering spree across London. Created by the author by overlaying lines between the shops in which she passed forged notes and the addresses at which she claimed to live on Edward Mogg's map, The Stranger's Guide to London [. . .] (London, 1806), in the Harvard Map Collection, Harvard University, https://id.lib.harvard.edu/curiosity/scanned-maps/ 44-990060632190203941, and adapted under Creative Commons License Attribution 4.0 International. Scale $1: 16896\left(3^{3} / 4\right.$ inches $=1$ mile on original $)$.

signatures of bank employees. Yet in the Old Bailey sample of uttering instances, only 7 percent of cases involved endorsing the back of a note with a name or signature only, compared to the 68 percent of cases that described both name and address being taken, underlining the relative importance of locality. Previous handwritten endorsements on the back of banknotes were also mentioned by retailers in 8 percent of cases, in part, it seems, as a way of identifying an individual note in the context of a criminal trial but also suggesting that traders examined annotations to see if they recognized any previous owners as a means of establishing authenticity. Thus when Richard Chappell, landlord of the Coach and Horses on Cross Street in Hatton Garden, was presented with a $£ 1$ note by Mary Singleton in 1820, he claimed that an existing endorsement on the back of the note made him accept it: "Seeing Ransom, Kirby-street, on it, I knew him, and thought it must be good." 70 Kirby Street was just under two hundred meters (around 220 yards) from Hatton Garden.

\footnotetext{
70 Trial of Mary Singleton, December 1820, t18201206-50, OBP, https://www.oldbaileyonline.org/ browse.jsp? div $=$ t18201206-50.
} 
Given the importance of local connections when assessing unknown customers and their banknotes, it is not surprising that more familiar and locally produced notes tended to be preferred over ones from distant towns. "Country notes"those produced in provincial centers outside London-were often met with distrust in the capital. In 1809, Sarah Morris tried to use a forged $£ 2$ Essex note in the shop of Robert Mackglew, a linen draper of City Road in Finsbury. The shopman William Cullen testified in court that, on seeing the note, "I perceived it to be of Westham, Essex bank; I gave it to John Spring, who has the management of the concern . . . he told the prisoner that we did not take country notes."7l Conversely, away from the capital, country notes seem to have been more trusted in the towns and regions in which they were produced. Peggy Houghton, who ran a public house in Preston with her husband, gave evidence at the Lancashire Assizes on 30 August 1817 against Robert Drake, testifying, "The prisoner gave me a country note. I said I did not like it, and would not take it . . . I take no country bank notes but the Blackburn." Drake had tried to pass another country note in Preston, at the inn of Mary Eastham, who claimed, "I would not take it, I didn't know the bank." Richard Proctor, a landowner from Bordley in the Yorkshire dales and former employer of the accused, gave Drake a character reference and reportedly stated on the subject of banknotes, "We don't like bank notes and we always change them for our country notes. . We don't like Durham notes, we like our own county best."72

Almost all of the court cases examined here described the capital's retailers inspecting banknotes before accepting them from strangers. This could be seen as either a standard cautionary practice on the part of shopkeepers, or something that witnesses felt they should tell the court to demonstrate that they had exercised due care. Finn notes a commonplace suspicion toward paper money persisting late into the nineteenth century. She quotes H. G. Wells's description in his autobiography of dealing with banknotes while working in a Southsea draper's shop in the early 1880s: "Bank of England notes were dealt with very solemnly," he wrote, while "the water-mark was scrutinized carefully and the payer, after a suspicious penetrating look or so was generally asked to write his name and address on the instrument."73 Wells's description of how retailers dealt with banknotes notably echoes the behaviors described in our sample of Old Bailey court records dating from over half a century earlier, suggesting a continuance of well-established practices. In 25 percent of instances of uttering in the sample from the earlier period, the appearance of a banknote was described as arousing suspicion, though in only a handful of examples was the reason given. In these cases, doubt was said to have been triggered for the most part by visual clues, often as notes were examined by candlelight in order to see them more clearly. Then it might appear that "the print [was] imperfect," the watermark was missing or deficient, a bank clerk's signature looked flawed, or the paper was the wrong color. ${ }^{74}$ Sometimes clues were haptic in nature.

\footnotetext{
${ }^{71}$ Trial of Sarah Ennever, alias Morris, 20 September 1809, t18090920-1, OBP, https://www.oldbaileyonline.org/browse.jsp?div=t18090920-1.

72 Times, 3 September 1817.

${ }^{73}$ H. G. Wells, Experiment in Autobiography, 2 vols. (London, 1934), cited in Finn, Character of Credit, 80.

${ }^{74}$ Trial of James Wooldridge, 14 January 1801, tl8010114-48, OBP, https://www.oldbaileyonline.org/ browse.jsp?div=t18010114-48; Trial of Thomas Clare, 6 June 1821, t18210606-58, OBP, https://www.
} 
The grocer and oil-shop keeper Caroline Warner noted that one counterfeit note she received "felt thicker than bank notes generally feel," while the butcher George Glover claimed that he had immediately suspected a banknote presented to him was a forgery as he had not found all its edges smooth; rather, "there were two rough sides. $" 75$

As has been suggested, checking banknotes by sight and feel in order to detect any abnormalities was something that individuals would have learned, either as part of deliberate educative practice on the part of employers or family members, or simply by watching other shopkeepers. Yet such knowledge did not necessarily enable traders to identify counterfeits in all cases, nor did it mean that individuals would want to make decisions trusting entirely to their own judgment. Though some shopkeepers, like Mr. Cobb, a grocer with a shop at the corner of Ivy Lane off Newgate Street, might have been confident in his own expertise in identifying counterfeits - in Cobb's case, "for he had, by most ruinous experience, become a tolerable judge of Bank notes"76_many did not feel themselves skilled or were as assured, and as a result sought assistance from others. Doing so might also have been a way of sharing the blame if a forgery was accepted, or of demonstrating that due care had been taken. But it is notable that while bank officials were almost always called on in court to give evidence concerning the authenticity of individual banknotes, ${ }^{77}$ and retailers who provided testimony in these cases often claimed to realize they had accepted a forged note only when they presented it to a bank, rarely did traders seem to turn to such institutional advice before accepting a note (only 2 percent of the Old Bailey sample). Far more frequently, expertise or opinion was sought much closer to home, from an employer, co-worker, a family or other household member, a neighbor, or a fellow trader. This practice was followed in 31 percent of the sampled cases, suggesting not just that retailers recognized the need to make relatively quick decisions so that they did not keep customers waiting-which meant that gaining advice from others nearby was more practical than traveling further afield-but also that expertise was not thought to lie only, or even predominantly, in institutions such as banks but rather within one's more immediate networks and locale. This was another way in which the local was favored over the more distant by retailers assessing banknotes presented by strangers. Witnesses in 9 percent of instances of alleged uttering in the Old Bailey sample described asking family or household members for their opinion of a suspect banknote. So when William Rhodes, a hosier and glover on Oxford Street, was given a $£ 5$ note that he "conceived. . . to be a bad one, as I thought," he noted that he "was not

oldbaileyonline.org/browse.jsp?div=t18210606-58; Trial of Elizabeth Webster, 6 June 1821, t1821060661, OBP, https://www.oldbaileyonline.org/browse.jsp?div=t18210606-61; Trial of George Dawson, 1 December 1819, t18191201-52, OBP, https:/www.oldbaileyonline.org/browse.jsp?div=t18191201-52; Trial of Francis Wooldridge, 14 January 1801, t18010114-56, OBP, https:/www.oldbaileyonline.org/ browse.jsp?div=t18010114-56; Trial of Thomas Edwards, 11 April 1804.

75 Trial of Sarah Dell, 13 April 1811, t18110403-59, OBP, https://www.oldbaileyonline.org/browse. jsp?div=t18110403-59; Trial of Mary Best, 13 May 1812.

76 Times, 29 March 1821.

77 Randall McGowen, "Knowing the Hand: Forgery and the Proof of Writing in Eighteenth-Century England," Historical Reflections/Reflexions Historiques 24, no. 3 (1998): 385-414. 
certain myself” and went upstairs to his wife who was ill in bed to ask for her guidance. $^{78}$

It was even more common to ask the opinion of neighbors, who were described as being explicitly or implicitly consulted about the authenticity of a banknote in 22 percent of the Old Bailey sample. In just under half of these cases ( 9 percent of the total sample), retailers appear to have explicitly sought advice about whether or not a note was genuine. Thus Margaret Corder recalled being called into the grocer's shop that she ran with her husband, William, on Broad Street in Bloomsbury in 1804. She described William as holding the note in his hand with the customers Sarah Whiley and Ann Haynes present and was said to have stated "that he was afraid it was a bad note, and he would step into Mr. Rider's, his next-door neighbor, and ask him."79 Similarly, a newspaper report in 1820 described Sarah Sparry, who ran a butcher's shop with her husband, John, on Rosamund Street in Clerkenwell, asking the opinion first of her husband, then of her neighbor John Emery, landlord of the John of Jerusalem public house on their street, before rejecting the $£ 1$ note that Eliza Smith had tried to use to purchase a part shoulder of mutton. ${ }^{80}$

Implicitly testing the validity of notes by asking a neighboring trader to provide change in exchange for a banknote was described in a further 13 percent of cases. Taking a banknote to a nearby shop to ask for change could avoid offending a customer by declaring that their note was suspicious. It may also have been necessary simply because a retailer genuinely did not have sufficient specie to complete a transaction, especially when the value of the banknote was large. Thus when William Algar, a shoemaker from near Wapping, was offered a suspect note in 1798 from Peter Dekclerk, a customer who was unknown to him, he claimed that he "took it and looked at it" but that he "did not like the appearance of the colour of the paper, and I did not like to change it, but sent it over to a neighbour opposite me." Algar's son, who had taken the note for his father, soon returned with it unchanged. Algar senior stated that he then sent it to another neighbor, Mr. Allybone, who would not change it either. Finally, he sent a servant to a Mr. Culland in Wapping, though he was careful to make clear that he sent it to him "only to inspect into it," lest he too be charged with uttering by asking for change for a note that had already been repeatedly refused. Only when Algar's maid returned with the note did he take it to the bank for a final opinion. ${ }^{81}$ No doubt motivated by similar concerns to neither accept a counterfeit note nor be accused of trying to pass one himself, the butcher William Bunyan of Lower Thames Street, told the Old Bailey that after receiving a suspect note in 1799 from Charles Linsey, he "took it to the public-house hard by, and I said, I think I have got a bad customer; I did not ask for change, but I asked for their judgment." 82 A report of a case brought before the Bow Street magistrates court in 1817 described a suspicious

\footnotetext{
78 Trial of John Troy, 29 May 1805, tl8050529-34, OBP, https://www.oldbaileyonline.org/browse.jsp? $\operatorname{div}=\mathrm{t} 18050529-34$.

79 Trial of Sarah Whiley and Ann Haynes, 11 April 1804.

${ }^{80}$ Trial of Eliza Smith, 28 October 1820, t18201028-45, OBP, https://www.oldbaileyonline.org/ browse.jsp? div=t18201028-45.

${ }^{81}$ Trial of Peter Dekclerk, 14 February 1798, t17980214-40, OBP, https://www.oldbaileyonline.org/ browse.jsp?div=t17980214-40.

82 Trial of Charles Linsey, 19 June 1799; Times, 24 June 1799.
} 
note being presented at the Phoenix Public House in Pimlico, and "the landlady of the house, not considering herself to possess sufficient knowledge of Bank-notes to determine whether good or not, and doubting the note from its extraordinary appearance sent it a neighboring cheese-monger to obtain his opinion by asking for change for it. The Cheesemonger refused to change it, saying it was not worth a penny," and as a result, she refused it as well. ${ }^{83}$

Seeking the opinions of household members and neighbors was surely driven in part by the ease and speed with which their views could be obtained. But the dependence on ways of establishing authenticity in which expertise was seen not as the preserve of remote bodies and institutions but instead resting in local networks and communities was another way that London retailers showed their preference for the local. Coupled with their frequent reliance on strategies that associated local residence and neighborhood relationships with credit and trustworthiness, the capital's traders appear to have operated in ways that we more readily associate with smaller communities and earlier periods. But this apparent contradiction can be explained. Although London was home to particularly high numbers of migrants who traveled to the city from other areas of Britain and from abroad, resulting in a uniquely mobile and anonymous population, this did not necessarily make it a city of strangers. ${ }^{84}$ London had long been described as consisting of a system of neighborhoods, each with its own character. ${ }^{85}$ Despite the high levels of mobility among its population during the long eighteenth century, Leonard Schwarz claims, the capital's neighborhoods "were in permanent flux and yet were remarkably stable," since the rich moved less often than the poor, individuals usually moved only short distances, and immigrants tended to congregate in groups. He argues that "an important corrective to the older views of the impersonality of large towns is that the larger a town, the more it is capable of supporting a substructure of local cultures." 86 Approaching the issue of urbanization somewhat differently by exploring the "magical imagination" in English towns during this period, Karl Bell also describes the continuance of neighborhood communities based on local identity that was defined both spatially and culturally. Their existence, Bell suggests, does not support the argument that modernity was seen as a sudden rupture from the past on the part of those who lived through it. ${ }^{87}$

The continuation of local communities or neighborhoods in London throughout the late Georgian period-which included those "imagined" communities that existed in the minds of inhabitants, even if they did not have a personal relationship with every member-goes some way to explaining why unknown customers could gain the confidence of shopkeepers simply by claiming to be local. ${ }^{88}$ This is not to

\footnotetext{
${ }^{83}$ Times, 23 October 1817.

${ }^{84}$ Leonard Schwarz, "London, 1700-1840," in Cambridge Urban History of Britain, vol. 2, 1540-1840, ed. Peter Clark (Cambridge, 2000), 641-72, at 652-53; Pamela Sharpe, "Population and Society, 17001840," in Clark, Cambridge Urban History of Britain, vol. 2, 491-527, esp. 493; Peter Laslett, The World We Have Lost_Further Explored (London, 1983), 75-77; Vernon, Distant Strangers, 7-8.

${ }^{85}$ M. D. George, London Life in the Eighteenth Century, 2nd ed. (London, 1965), 9-10; Burke, "Imagining Identity in the Early Modern City," 29-30.

${ }^{86}$ Schwarz, "London, 1700-1840," 654.

${ }^{87}$ Bell, Magical Imagination, 260-61.

88 Zygmunt Bauman, Modernity and Ambivalence (Cambridge, 1991), 246; Benedict Anderson, Imagined Communities: Reflections on the Origin and Spread of Nationalism (London, 1983); Eric Hobsbawm,
} 
say that change was not apparent in the capital, so that contemporaries might also wonder at the anonymity of large towns-and London in particular-with several commentators in the early nineteenth century remarking that people did not know their own neighbors. ${ }^{89}$ But both reactions to the "confusion and chaos of the early industrial city" - the belief in the continuance of local communities and in the pervasive rise in anonymity - can coexist. ${ }^{90}$ Moreover, the embrace of the local can be seen as a defense tactic in the midst of uncertainty, so that one of the impacts of the developments associated with modernity, such as rising anonymity, was to increase the value of the local and the seemingly tangible. Thus a society in which abstract and distant institutions, such as banks, mattered increasingly, in part because of their expertise, was also one that simultaneously encouraged a dependence on local "nonexpert" networks.

By shedding light on their day-to-day commercial practices, this study of traders' responses to the threat of banknote forgery suggests that they experienced and imagined the city in which they lived and worked as rather less incoherent and disordered than is sometimes assumed. Instead, they relied on a series of techniques that previous experience suggested usually worked: examining banknotes and those strangers who presented them with care, relying on the expertise and opinions of neighbors and members of their household, and preferring to deal with individuals who appeared to be linked to their local community. Though such behavior was not without risk-as the court cases which form the basis of this study demonstrateit seems likely that traders hoped that losses to fraud were outweighed by the gains of additional custom, so that the tactics they used can be seen as firmly rational despite being occasionally very costly. ${ }^{91}$ Tradesmen and women were nothing if not pragmatic, as their behavior concerning unknown customers and the risks of banknote forgery underlines, but they also demonstrate that many of the developments that have been associated with modernity might affect the lives and outlooks of ordinary Londoners in unexpected and seemingly contradictory ways, some apparently strongly linked to older forms of society. As Bernhard Reiger and Martin Daunton have argued, emphasizing the discontinuities between modernity and its antecedents overlooks the fact that "on many occasions, Britons understood modernity in terms of continuity and not exclusively in terms of fundamental rupture," so that dual models of change existed in which "gradual transitions also stood alongside. . . sudden transformations. ${ }^{92}$

\footnotetext{
"Introduction: Inventing Traditions," in The Invention of Tradition, ed. Eric Hobsbawm and Terence Ranger (Cambridge, 1983), 1-14; Lofland, World of Strangers, 22.

${ }^{89}$ Burke, "Imagining Identity in the Early Modern City," 29.

${ }^{90}$ Lofland, World of Strangers, at 66; Vernon, Distant Strangers, xi, 7.

${ }^{91}$ On risk-taking and competition, see Julian Hoppit, Risk and Failure in English Business, 1700-1800 (Cambridge, 1987), 51-55; John Smail, "Credit, Risk and Honor in Eighteenth-Century Commerce," Journal of British Studies 44, no. 3 (2005): 439-56; Nancy Cox, The Complete Tradesman: A Study of Retailing, 1550-1820 (Aldershot, 2000), 146-62; Stobart, Sugar and Spice, 150-57.

92 Daunton and Reiger, introduction, 12.
} 